\section{CROP PROTECTION}

\section{SYMPOSIUM IN GHENT}

$\mathrm{T}$

HE annual symposia on crop protection, held at

the College of Agriculture, Ghent, have attracted larger numbers each year since the present rector of the College, Prof. J. Van den Brande, organized the first meeting in 1948, and at the meeting this year, held on May 5, some two hundred and fifty persons participated. Although the majority were from Belgium and Holland, representatives from several other countries were present. The opening address by Prof. Van den Brande in the morning was followed by two simultaneous sessions for the reading of papers, and during the afternoon a further five papers were read.

Dr. J. G. ten Houten (Wageningen) gave an excellent general survey of the research now proceeding in the Netherlands on plant diseases and pests and their control. In the work on apple scab, the correlation between temperature and duration of wetting of apple leaves in relation to the primary infection and incubation periods for Venturia incequalis, as established by Mills in the United States, has been confirmed under the climatic conditions prevailing in the Netherlands. By spraying eradicant fungicides (organo mercury compounds) up to five days after infection took place, it was possible to control apple scab by only three sprayings against the six required with protective fungicides like lime sulphur. Spraying with organo mercury compounds, however, can only be used on non-susceptible apple

varieties, and such treatments should not be made after ascospore discharge has ceased. Research on the Rubus stunt virus of raspberries has shown that diseased shoots can be completely freed from the virus by immersion in water at $45^{\circ} \mathrm{C}$. for $1-3$ hours. Excellent control of the pea moth (Enarmonia nigricana) attacking canning and other peas which are harvested early has been consistently obtained by one application of parathion when the lower pods are about three-quarters grown. Toxicological trials indicate little consumer hazard if the recommended procedure is adopted. The potato root eelworm (Heterodera rostochiensis) is a serious pest in Holland, and to grow potatoes in infested soils or to take a potato crop more than once every three years from non-infested soil is prohibited by law. A team of research workers is concerned with the control of this pest. 'The investigations include soil treatment with chemicals, finding the substances in potato root extracts responsible for the hatching of the cysts, the possibility of using parasites (fungi and a newly found amcba), and breeding resistant potato varieties. The control of cyst-forming eelworms with "DD mixture" was the subject of a paper by Dr. J. Th. W. Montagne (Amsterdam), in which be said that soil treatment with the chemical combined with a short crop-rotation has been found to give the best results. Prof. Van den Brande, R. H. Kips and J. D'Herde (Ghent), also studying the eelworm problem, described how they had examined some of the newer systemic insecticides for nematocidal action. Again, Dr. M. Oostenbrink and Dr. A. F. H. Besemer (Wageningen) showed that a root rot disease in chrysanthemums, pyrethrums and other flowers grown for cutting is associated with parasitic eelworms. Large numbers of Meloidogyne sp. and Pratylenchus sp. were present in the sick fields, and it had been shown that attack by these pests was a primary cause of the disease, the fungus attack probably leading to the final collapse of the root. Soil fumigation with chloropicrin gave the most effective control.

Several papers were concerned with weed control. M. Slaats and J. Stryckers (Ghent) showed that under certain conditions ammonium dinitro-ocresylate can be used for controlling weeds in hybrid maize; hormone-type weed killers damage the crop. Dr. F. H. Feekes (Barrn) discussed his work on the use of isopropyl-N-phenyl carbamate and sodium isopropylxanthate as selective weed killers. A striking control of chickweed (Stellaria media) was achieved with the former substance at $10 \mathrm{lb}$. an acre.

Dr. G. J. M. Van der Kerk (Utrecht) described a new group of organic fungicides which has arisen from his work on dithiocarbamic acid derivatives. These compounds are the $\mathrm{N}$-phenylrhodanines with para substituents in the benzene ring (I). The most active compound so far obtained is $p$-phenylenebisrhodanine (II), which, against the four fungi tested, is at least as fungicidal as the most active of the dithiocarbamic acid derivatives now used in erop protection.<smiles>O=C1CSC(=S)[NH+]1c1ccccc1</smiles>

I

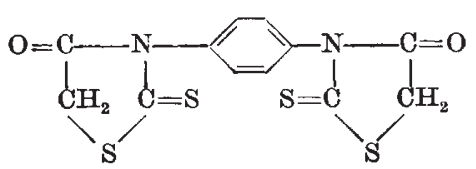

II
Another paper concerned with fungicides was presented by L. Bravenboer (Naaldwijk), who discussed his attempts to correlate the degree of control of Cladosporium cucumerinum obtained in practice with the results of laboratory experiments. Prof. R. L. Wain (London) reviewed the present position of systemic fungicides; he gave an account of the more recent British and American work in this field and described the investigations being carried out in his department with aryloxyalkylcarboxylic acids and other compounds. M. J. Zwijns (Maarssen), in discussing seed disinfectants, said that tetramethylthiuram disulphide has given excellent results as a seed dressing for beets, beans, peas, corn, flax and other crops ; 2 : 3-dichloro-1 : 4-naphthoquinone and tetrachloro-1 : 4-benzoquinone have also proved satisfactory. R. Bovigne et al. (Gembloux) outlined the results of experiments using tetrachloronitrobenzene, methylnaphthyl ethyl ether, methyl $\alpha$-naphthylacetate and isopropyl- $\mathrm{N}$-phenyl carbamate for preventing the sprouting of potaloes. Dr. H. FrankeGrosmann (Reinbek-Hamburg) gave an interesting account of how the gall mite Aceria gemmarum (Nalepa) became a serious pest on willow following the use of DDT and BHC against leaf-eating beetles and weevils (Phyllodecta vulgatissima and Pselaphorhynchitis spp.); much damage was caused in Salix viminalis $f$. regalia, whereas $S$. americana was attacked to a much less extent.

Other topics discussed were the value of the Fischer index as a means of estimating the keeping qualities of suspensions (P. H. Martens and J. Henriet, of Gembloux), the control of the cabbage seed-pod weevil with BHC and parathion (Prof: J. H. Schuurmans-Stekhoven, of Deventer), experience in the Netherlands with new types of acaricides 
(A. F. H. Besemer and K. Hartsuyker, of Wageningen), a new method of applying pest control materials to plants (Prof. P. Froeschel, of Ghent) and a biological method for assessing residual parathion on cabbage leaves (Dr. J. J. Fransen, of Arnhem).

The organizers are to be congratulated on the satisfactory arrangement and smooth running of this successful symposium.

R. L. WAIN

\section{RESEARCH IN RURAL ELECTRIFICATION}

\section{WORK AT THE ELECTRICAL RESEARCH ASSOCIATION}

$\mathrm{A}$

$\mathrm{N}$ open week, beginning on May 4, was held at the Field Station at Shinfield, near Reading, of the Electrical Research Association, and Mr. G. R. H. Nugent, parliamentary secretary of the Ministry of Agriculture and Fisheries, a Ministry which makes a substantial contribution to the work of the Association, officially inaugurated the proceedings.

The Electrical Research Association established its Rural Electrification Section in 1938 with the main object of developing equipment and operating techniques which are satisfactory to the farmer or grower and which, at the same time, present load characteristics favourable to the economic supply of electricity. The larger the energy taken by rural consumers, especially during off-peak periods, and the lower the power demand, the greater the possible economy. Mr. Nugent emphasized the benefit of electricity on the farm, especially in saving labour and thus increasing production with the present labour force, and also in providing amenities for farm workers to encourage them to stay on the land rather than to succumb to the attractions of the town. A large, and rapidly increasing, number of farms now have electricity, but too many of them fail to make full use of it. Although electrio light and domestic power are certainly valuable, much fuller advantage should be taken of electrical methods in agriculture and horticulture. The Ministry, said Mr. Nugent, is fully in agreement with the aims of the research work at Shinfield; economic considerations are rightly kept to the fore in the development of new applications of electricity on the farm.

At the Field Station, basic research determines the form of equipment and the technique required for electrical operation. This is followed by full-scale tests and later by trials under practical conditions on farms and horticultural holdings in different parts of Britain. The co-operation of the agricultural research establishments and of farmers and growers is an essential feature of work of this kind, and the Association has been fortunate in obtaining such co-operation both from its neighbours - the University of Reading and the National Institute for Research in Dairying-and from others much farther afield.

The underlying principle in many of the investigations is simplicity of operation, with electrical methods involving low kilowatt loadings which can be used for a lengthy period. These are much more welcome to electricity supply than the high shortperiod loads which present difficult problems in rural electrification.

A number of researches already completed have formed the basis for equipment which is now com- mercially available. Among these are : barn haydrying, a method of producing very high quality hay by blowing cold, or slightly warmed, air through grass stacked in the barn ; a low-powered automatic hammer mill for farm grinding; a soil sterilizer of the immersion type for potting soil ; and soil warming in frames and glass-houses by a simplified method in which a daily 'dose' of energy provides beneficial soil warmth but avoids the large consumption needed to maintain a suitable fixed temperature. Work now in progress on the horticultural plots aims at further improvement of the soil-warming technique and at finding the crops and varieties for which it is most likely to be economical in frames, under cloches and in open ground.

In the glass-houses, electric space-heating is used in combination with soil-warming, and different arrangements and forms of construction are being studied to reduce heat losses and so to minimize operating costs. Artificial illumination, using various kinds of lamps and of lighting fittings, is being applied to the raising of tomato seedlings. Laboratory work on soil sterilization by the electrode method, in which current is passed directly through the soil, is preliminary to in situ sterilization of glass-house soil. A model glass-house in the exhibition was fitted with many devices which may be developed in future for the complete control of all the factors involved in growing plants to perfection. Presuming that the plant physiologists achieve their goal, this is the ultimate object of the researches now in progress.

Laboratory work on the agricultural side is concerned with the requirements for drying many kinds of agricultural materials and with their equilibrium moisture content in different atmospheric conditions. Grain drying, grass drying and seed drying are studied experimentally, and a novel form of moisturemeter for grain has been developed. A 'farm of the future' in the display showed many new agricultural applications of electricity which, in combination with existing ones, could be used to provide an approximately constant load throughout the year. They would both save labour and give a high load-factor on the farm.

An electrically driven tractor which has been used for the cultivation work at the Field Station during the past three years has the advantages of simple and quiet operation, low running and maintenance costs, and ample tractive effort over a wide range of speeds.

In conjunction with the University of Reading poultry farm, investigations are being made on the possibilities of electrical methods in poultry husbandry. These include air-conditioning for laying hens, the effect of environment on the growth of chicks, and flash illumination in laying-houses as an energy-saving alternative to the usual artificially exterided daylight. The destruction of pests by the use of high-frequency fields, the killing of weeds by an electrical discharge and fish-stunning by passing a current through the water in streams or in the sea, are other subjects studied. An experimental heat pump is used for heating one of the laboratory buildings, and its performance is being tested by comparison with that of a conventional plant in another building with similar thermal characteristics. The heat-pump principle is also being applied to dairy work with the object of using heat removed from milk in cooling it to heat water for washing. 